\title{
Nationalist Thought and the Sri Lankan World
}

This chapter unfolds in three sections. Section 1 explores how in the early twentieth century the songwriter John De Silva (1857-1922) and poet Ananda Rajakaruna (1885-1957) created Sinhala song and poetry in service of the Sinhalese Buddhist revival. I suggest that De Silva's songs and Rajakaruna's poetry can be considered characteristic of cultural forms created in the first stage of Partha Chatterjee's three-stage theory of anticolonial nationalist thought-departure, maneuver, and arrival. ${ }^{1}$ In the moment of departure, elites familiar with nineteenth-century Western European concepts such as culture, nationalism, and progress used texts (essays, novels, dramas, poems, songs, etc.) to resist Westernization and advocate for religious, moral, or social reform, but they simultaneously maintained faith in English rule and did not attempt to question the legitimacy of British rule in South Asia. For example, in addition to De Silva's dramatizations of Sinhalese Buddhist history, he also staged Sinhala-language versions of Shakespeare's Othello (1909), The Merchant of Venice (1909), and King Lear (1913), and he published a book of children's poetry in 1919 that included a poem about the English flag. ${ }^{2}$

Section 2 turns to the Venerable S. Mahinda's political poetry of the 1930s. I read Mahinda's works as examples of Chatterjee's second stage, the moment of maneuver. The moment of maneuver happens when members of the middle class mobilize local elements of traditional culture to rally people against colonialism in the struggle for independence. Because Mahinda combined a Sinhala chronicle with a Sinhala lullaby to incite his readers into anticolonial rebellion, one can argue that his poetry should be considered an example of Chatterjee's moment of maneuver. 
The final section of this chapter presents an instance of cultural production that deviates from Chatterjee's model. Through an analysis of Sinhala gramophone songs created in the late 1930s, I assert that Chatterjee's three moments are not capacious enough to detect the connections between cultural nationalism and cultural commodities. In other words, Chatterjee's insular model does not account for the way in which cultural nationalism and global capitalism became intimately related in colonial-era South Asia. ${ }^{3}$ I attempt here to explore an overlooked feature of cultural nationalism, one fueled more by capitalism than the desire to cultivate patriotic sentiment or ethnic loyalty. Gramophone songwriters drew on the spirit of the moments of departure and maneuver, yet not for nationalist ends. Rather, they channeled the ethos of the moments of departure and maneuver into their song lyrics. Composers and arrangers then set these lyrics to already-composed melodies of popular Indian film songs. The goal was not nationalist but capitalist: sell records to make a profit.

Because I attempt in this chapter to draw on, criticize, and expand Chatterjee's model of nationalist thought, I must inform the reader that my primary sources diverge from those of Chatterjee. To trace out moments of nationalist thought the sources Chatterjee, a political theorist, focuses on are Bengali- and Englishlanguage essays written by one novelist, Bankimchandra Chattopadhyay, and two leaders of the Indian independence movement, Mahatma Gandhi and Jawaharlal Nehru. These men were fluent in either Bengali, Gujarati, or Hindi but were also fluent in English and well read in the works of Western European social scientists and political theorists such as Auguste Comte, John Stuart Mill, and Herbert Spencer, as well as orientalists such as William Jones, H. H. Wilson, Thomas Colebrooke, and Friedrich Max Müller. Chatterjee analyzes how Chattopadhyay, Gandhi, and Nehru's nationalist thoughts were different from but deeply rooted in or positioned against (in the case of Gandhi) such forms of post-Enlightenment scientific thought.

In contrast, to trace what I am also identifying as "moments of nationalist thought," the sources I study in this chapter are Sinhala-language theater songs, poems, and gramophone songs composed by librettists, poets, lyricists, and composers. There is no evidence to suggest that these individuals had read Comte, Mill, and Spencer or Jones, Wilson, Colebrooke, and Müller. But they did have contact with the ideas of Indian elites such as Gandhi and Nehru. Poets such as Rajakaruna and Mahinda, for example, praised Gandhi and Nehru in their poems. ${ }^{4}$ In one poem Mahinda instructed his readers to pay attention to the words and actions of India's anticolonial leaders, such as Mahatma Gandhi, Jawaharlal Nehru, and Vallabhbhai Patel:

Heroes like Gandhi, Nehru, and Patel

Fight day and night for independence.

Sinhalese brothers, listen to their words

And come forward for the island's national cause (v. 41$)^{5}$ 
Ultimately, then, a major weakness in Chatterjee's argument, which has informed the works of many scholars in South Asian studies, is that he believed his study of Bengali and English sources had implications not only for India but also for nationalist thought in all colonial countries: "The theoretical structure of my argument must stand or fall at the general level, as an argument about nationalist thought in colonial countries and not as an argument about Indian nationalism." ${ }^{\circ}$ Such an assumption is problematic because Chatterjee overlooked power relations within South Asia and assumed all intellectuals in South Asia had as direct experience with the West as did internationally renowned leaders like Gandhi and Nehru. The works of songwriters and poets from Sri Lanka provide a case study that contradicts Chatterjee's assumptions, because Sinhalese songwriters and poets often did not directly encounter post-Enlightenment notions and European cultural forms but encountered such ideas and forms after they had been interpreted by Indian elites.

\section{A MUSICAL MOMENT OF DEPARTURE}

To understand the moment of departure for Sinhalese nationalism one must search for revivalist efforts to create a new modern culture for a nation. Such an effort is evident in a Sri Lankan cultural movement referred to as the "Buddhist revival." ${ }^{\prime}$ Historians of Sri Lanka have revealed how the revival became stronger in the mid-nineteenth century with the help of the first Sinhala periodical, printing press, and newspapers. Print culture created a public space in which Sinhalese Buddhists could respond to the Christian missionaries' attacks on their religion. The revival grew more persistent with the support of urban entrepreneurs who established voluntary organizations to propagate Buddhism.

Also contributing to the revival's success was the Buddhist monastic community, which adopted a more public and activist role. In the 1870 s Ven. Migettuwatte Gunananda (1823-90) organized societies, established a printing press, toured the island disseminating his message, and confronted Christian missionaries in publicly staged debates. Ven. Hikkaduwe Sumangala (1827-1911) helped set up a printing press and authored polemical works that rebutted the Christian missionaries' criticisms of the Buddhist religion.

The revival further expanded in the late nineteenth century because of two international organizations: Henry Steel Olcott's Buddhist Theosophical Society, which built a Buddhist educational system that rivaled the missionary system in Sri Lanka; and Anagarika Dharmapala's Maha Bodhi Society, which strove to propagate the Buddhist religion and reestablish Bodh Gaya in North India as a center for Buddhist pilgrims. (Bodh Gaya is where the Buddha is said to have achieved nirvana. $)^{8}$ 
Dharmapala and his colleagues championed a form of ethnic identification called the "Arya-Sinhala" identity. "Sinhala" refers to the Sinhalese people, but the word "Arya" was a new appendage to designate the ethnic group. The "Arya" identity appealed to the urban Buddhist intelligentsia for a few reasons. First, they believed Prince Vijaya, the putative father of the Sinhala race, emigrated from a region in North India referred to in Sanskrit texts as the aryavarta. Second, the word arya in the Pali language (the sacred language of Theravada Buddhism) connoted meanings like noble, worthy, and honorable. In Buddhist texts arya was an adjective used to glorify central concepts in the Buddha's teachings, like the four noble truths (caturariya sacca) and the noble eightfold path (ariya atthangika magga). ${ }^{9}$ Revivalists promoted the Arya-Sinhala identity in early journals such as Aryaya (The Aryan, 1909) and Arya Sinhala Vamsaya (The Aryan-Sinhalese lineage, 1912).

Scholarship on the revival tends to focus on religious reform and overlook the participation of songwriters and poets, social actors that also shaped the contours of the movement. Admittedly, John De Silva engaged with the revivalist issues that became commonplace, like edification, temperance, and education about Sinhalese history and Buddhism. Yet because De Silva became involved with these issues as a librettist (rather than as a Buddhist monk), one must also take into account the Indian theatrical innovations that inspired him.

The original inspiration for De Silva's musicals owed as much to the revival as to a pan-South Asian dramatic form known as the "Parsi theater." The word "Parsi" refers to the Zoroastrian community in North India, the community from which the creators of Parsi theater belonged. Parsis organized the first modern theater companies in South Asia and created a form of entertainment, performed in Gujarati, Urdu, or English, which was based on European dramas that divided plays into acts and scenes. ${ }^{10}$

In 1877 , as the revivalists championed the Arya-Sinhala identity, a Parsi theater troupe from Bombay named the Hindustan Dramatic Company brought a new form of theater to Sri Lanka as well as the North Indian musical system of räga and tâla. ${ }^{11}$ The Parsi theater troupe presented two Urdu-language dramas with stories narrated with poetry, dance, and music. One was Indar Sabha, considered the very first Urdu-language drama. ${ }^{12}$ In 1882 another troupe, K. M. Baliwala's Elphinstone Dramatic Company, presented Indar Sabha along with at least seven new musical dramas. The Parsi theater troupes from Bombay returned to Sri Lanka six more times between 1889 and $1913 .{ }^{13}$

The Parsi theater was perhaps the earliest modular form of popular culture in modern South Asia. Kathryn Hansen has written about the way that Parsi theater producers created a form of entertainment that appealed to a wide spectrum of urban audiences across the Indian subcontinent. ${ }^{14}$ The Parsi theater also captivated audiences in Sri Lanka with its lavish stage designs, shiny costumes, new curtain technology, and songs with memorable North Indian melodies. Parsi theater melodies, in fact, contributed to the genesis of a new form of Sinhalese theater. 
Playwrights began to create Sinhala-language scripts with songs set to melodies from the Parsi theater. Their musicals were called nurthi, from the Sanskrit word for drama, nritya.

Nurthi musicals show the confluence of the Parsi theater with the Buddhist revival, and the revival's promotion of the Arya-Sinhala identity. The first nurthi playwright, C. Don Bastian (1852-1921), would publish the first daily Sinhala newspaper, Dinapata Pravurti (The daily news, 1895) and establish a voluntary Buddhist organization named Gnanabhivriddhi (Development of Wisdom). ${ }^{15}$ After seeing the Parsi theater of the Hindustan Dramatic Company, Bastian wrote and staged the first nurthi musical, Rolina (1877), a tale of a heroic princess who saves her husband's life. ${ }^{16}$

The Buddhist revival would become the dominant theme in the nurthi musicals of John De Silva. He was determined to use theater to resuscitate Sinhalese Buddhist culture, which he thought was rapidly disintegrating under the onslaught of colonialism. ${ }^{17}$ De Silva was a lawyer by profession and would frequent Bastian's nurthi musicals. Like Bastian, De Silva set his lyrics to Parsi theater melodies. ${ }^{18}$ His audience predominantly comprised the Buddhist middle class in Colombo, yet Christians too supported De Silva's productions. This is evident in the list of donors that De Silva listed in his diary. ${ }^{19}$

In 1902 De Silva established the Arya Subodha Drama Society to harness theater for the revival. To this end, his musical Śrī Vikrama Rājasinghe (The great king Vikrama Rajasinghe, 1906) valorized the life of the last Buddhist king prior to British colonization of the island. In the printed musical's preface, De Silva explained that he had established the drama society to loosen the grip of Western lifestyles on the Sinhalese and reunite them with their Arya-Sinhala Buddhist heritage. Other objectives De Silva held for the drama society were to put on display traditional Sinhalese customs and costumes, attack poor character traits, foster love for the Sinhala language, and refamiliarize the Sinhalese people with Sinhala music, which he believed was quickly disappearing. ${ }^{20}$

De Silva, however, did not suggest that Sinhalese folk music was disappearing because of rapid urbanization. Instead, he wanted to reacquaint the Sinhalese people with North Indian classical music. The preface he wrote in 1903 sheds light on his preference for Indian classical music:

There is evidence that Indian classical music existed in ancient Lanka during the times of our Sinhalese kings. Consider where Sinhalese poets of the past took their poetic meters. A careful analysis shows that Sinhala poetic meters originally belonged to the system of rāga [Indian melodic modes] and tāla [Indian rhythm cycles] found in North Indian classical music. Take the famous Sinhala samudraghōsa meter [quatrains, each line with eighteen syllabic instants].... When you read texts on North Indian classical music you find that musicians performed the tāla khyāla with the rāga pilu. Our samudraghōṣa meter has the same structure of khyāla [a rhythmic 
cycle with four eighteen-beat sections]. Since the poetic meter of our ancient poets is structurally similar to this tāla we can surmise that Sinhalese people had a sound knowledge of Indian classical music. ${ }^{21}$

De Silva believed that the eighteen syllabic instants found in the local samudraghossa poetic meter derived from an eighteen-beat North Indian rhythmic cycle, and he hypothesized that other Sinhala poetic meters originated in the tradition of North Indian classical music. Believing this to be true, he justified his own use of North Indian classical music as an authentic expression of the Arya-Sinhala cultural ethos.

Later in his career De Silva frowned on nurthi songwriters who imitated Parsi theater melodies. ${ }^{22} \mathrm{He}$ came to believe that nurthi songs should be original creations that drew on Indian classical music. Hoping to improve the music of his dramas, De Silva paid a well-known musician from western India named Visvanath Lawjee to come to Sri Lanka. De Silva and Lawjee developed a particular way of working together. Lawjee did not know the Sinhala language, so De Silva explained the scene to Lawjee in English. Lawjee drew on his knowledge of North Indian rāgas to compose a suitable melody for the scene. After Lawjee completed a melody, De Silva would compose Sinhala lyrics that matched the musical rhythm of Lawjee's new melody. ${ }^{23}$ Lawjee would go on to compose the music of De Silva's most famous nurthi musicals. De Silva staged these musicals between 1903 and $1909 .^{24}$

Arguably, De Silva and Lawjee's most well-known collaboration is "Dannō Budunge"” (Abiders of the Buddha's dharma). De Silva featured the song in his musical Sirisangabō Charitaya (The character of Sirisangabō, 1903). Consider De Silva's song lyrics:

Sānghatīssā: Behold in this mansion-like town

Many monks adhering to the precepts

Destroying their defilements

And abiding by Buddha's dharma teachings

Sirisānghabō: Like heaven on earth!

The shade of the many monks

Who travel by air

Destroy hot sun rays

Gōthābhaya: I see flocks of ducks wading

In deep ponds, where stems of

Lotus and lily flowers

Rise to the top ${ }^{25}$

The narrative of Sirisangabō Charitaya was derived from a tale out of the oldest historical literature in South Asia: the Pali-language Mahāvamsa of the fifth 
century C.E. De Silva based Sirisangabō Charitaya on the story found in the thirty-sixth chapter of the Mahāvamsa. The thirty-sixth chapter is about a virtuous king named Sirisānghabō. He and two friends, named Sānghatīssā and Gōthābhaya, travel to the royal city of Anuradhapura to serve the Sinhalese king. "Dannō Budungē" described Sirisānghabō’s, Sānghatīssā’s, and Gōtḥābhaya’s initial reactions as they walk through the entrance to Anuradhapura and behold the city.

De Silva thus aimed to praise the sacred qualities of the city of Anuradhapura, the capital of early Sinhalese Buddhist kingdoms. He described Anuradhapura as a heaven ("Like heaven on earth!"), an idea Sinhalese authors frequently used in classical Sinhala poetry. In the second stanza Buddhist monks travel through the air and cast a cooling shade on the people below. De Silva may have meant to allude to the fact that the compassion of Buddhist monks cools down the fear laypeople feel in the worldly existence, rebirth after rebirth. ${ }^{26}$

\section{A POETIC MOMENT OF DEPARTURE}

The moment of departure-the moment elites began to mobilize the arts for social, religious, or moral reform-occurred in Sri Lanka not only in musicals but in didactic poetry, too. South Asian studies scholars have documented how didacticism in the nineteenth and early twentieth centuries became a primary feature of poetry in many South Asian languages. Karine Schomer discusses how Hindi poets of the early twentieth century (the Dvivedi poets) came under the influence of Mahavirprasad Dvivedi (1864-1938) and consequently changed the themes of poetry from religious to didactic. ${ }^{27}$ Dvivedi poet Hariaudh's (18651947) Priyapravās (1914), for instance, reinterpreted the Krishna myth to encourage women to engage in social work. Similarly, Tamil and Telugu poets in the nineteenth and early twentieth centuries rejected eighteenth-century Tamil and Telugu poetry about sensual women and lovemaking. Like the Dvivedi poets they sought to make poetry a vehicle for social reform. Telugu poet C. R. Reddy (1880-1951), for example, reworked the erotic eighteenth-century Telugu poem "Bilaniyamu." In the original "Bilaniyamu" Bilhana falls in love with his student Yāmini. In Reddy’s version Nava Yāmini (New Yamini), Yāmini admonishes him for his immorality and shows him the way to a virtuous life. Velcheru Narayana Rao attributes the moralist tendency in Telugu poetry to the manner in which the British Raj disseminated Christian or Victorian moral beliefs in the guise of a universal ideology about "civilized culture." ${ }^{28}$ Telugu poets under the influence of this powerful ideology began to view premodern Indian literature as obscene. $^{29}$

Given that Sri Lanka was a British colony like India, it is not a coincidence that Sinhala poets in the early twentieth century had come into contact with the same 
Christian and Victorian moral beliefs and tended to utilize verse for didacticism and reform. Their works were as bound up with the Buddhist revival as was De Silva's theater songs. The poets of the early twentieth century are known as the "first-generation Colombo poets." They published in Sinhala-language newspapers that propagated the revival and disseminated their works through a wide range of new publications that included monthly journals, children's journals, and popular journals devoted exclusively to Sinhala verse. ${ }^{30}$ Many of the first-generation Colombo poets were schoolteachers, headmasters, editors, journalists, or Buddhist monks. Many were active participants in literary societies, especially the All-Ceylon Poets' Congress, established to propagate Sinhala-language poetry. ${ }^{31}$ The first president of the All-Ceylon Poets' Congress was Ananda Rajakaruna, arguably the most revered Sinhalese poet of the early twentieth century. In this section I explore Rajakaruna's poetic moment of departure through the lens of his didactic poems that advocated for temperance, spiritual purification, linguistic conservatism, and chastity.

In 1913 Rajakaruna completed a poem of 127 stanzas titled Raja Sirit Mālaya (The garland of kingly customs). He entered it into a poetry competition sponsored by the Colombo Temperance Society, the leading voluntary association that advocated that Sinhalese people abstain from alcohol. As Michael Roberts notes, "The temperance associations themselves were but one expression of the burgeoning Sinhala cultural renaissance and the associated thrust of Buddhist revivalism." ${ }^{32}$ Rajakaruna won the top award in the competition. In the poem's opening stanzas, he idealistically praised Sinhalese ancestors who he claimed abstained from alcohol:

Young and impressionable

Sinhalese children:

Study the garland of kingly customs

To develop love for the nation

Our great ancestors

Who maintained the precious heritage of Sri Lanka

Ordered us directly

Not to drink alcohol. (vv. 1-2) 33 $^{33}$

During the late 1910 and early 1920s, Rajakaruna served as a teacher, headmaster, and then journalist and editor. While he was a newspaper editor for the Sinhala Baudhayā (The Sinhala Buddhist), a mouthpiece for the Buddhist revival, Rajakaruna authored a weekly column titled Danumäti Hāmi (Wise man). Like John De Silva in his nurthi plays, Rajakaruna in this column attacked Western ways of living and urged the Sinhalese to return to Arya-Sinhala Buddhist customs. ${ }^{34}$

Throughout the 1920 s Rajakaruna published many didactic poems. Consider one stanza from a poem he published in 1921 in a monthly journal titled Diniňdu Räs (The sun's rays): 
We waste all the water of the ocean to clean our bodies.

We use a whole mountain of things to beautify our body.

Can we ever rid ourselves of defilements

By beautifying our body? (v. 1$)^{35}$

Here Rajakaruna criticized Sinhalese people who pampered their bodies, and he advocated for spiritual purification. He published the poem at a time when Sinhalese nationalists were critiquing Western consumer products like soaps, perfumes, and powders that had become popular. The same year Rajakaruna authored "Avavādayak" (A piece of advice) in a children's journal titled Lamayingē Mitraya (Children's friend). In this poem, he championed linguistic conservatism, finding fault with Sinhalese children who flippantly mixed Sinhala with English.

Some children who do not know the Sinhala language

Talk in English like it's a big thing.

These children commit a grave offense

And destroy our nationality (v. 1) ${ }^{36}$

Rajakaruna ridiculed their dialect in the next stanza. In my translation I have placed in italics the English words that Rajakaruna spelled out in Sinhala letters:

"Tomorrow Mrs. Vandebonair might come"

"Ms. Johanna might wear a short dress and go shopping"

"He's a real jolly fellow" "Victor, look at my piano"

See how they talk! Their accharu language is a travesty (v. 2$)^{37}$

I present here the transliterated form of this poem precisely as Sinhala metered poetry appears in print, that is, with the final like-phoneme separate from the rest of the line. The English words are italicized:

$\begin{array}{ll}\text { heța savasa mehē ēvī misis vändebō } & n \bar{a} \\ \text { koța gavom aňdan dän yay șopin mis johā } & n \bar{a} \\ \text { kadima joli felō vicțar lukät may piya } & n \bar{a} \\ \text { kiyana sätị balav "accāru" bāsen aňdō } & \text { nā }\end{array}$

To mix the mother tongue with English, Rajakaruna argued, was like carelessly tossing together ingredients to make accaru, a mixture of pickled fruits and vegetables introduced into Sinhalese cuisine through the Sri Lankan Malay community.

Similar to Hariaudh's and Reddy's moralist tendencies mentioned at the beginning of this section, Rajakaruna also expressed Victorian ideals about sexual mores in his poetry. Ralph Peiris, a sociologist of Sri Lanka, writes that in nineteenth-century Sri Lanka, sexual relations had been "considered more as casual and inevitable incidents in a person's life." ${ }^{8}$ Yet by the 1920 s British, Christian, and Victorian morals may have influenced Rajakaruna to compose a poem such as 
"Kumaribambasara" (Young girl's celibacy, 1923). In the opening stanza he urged women to maintain chastity before marriage:

Parental love allows her to grow into a maiden

Like the moon that blossoms the water lily.

Beautiful, her heart of gems and treasures is

Unstained by lustful touches (v. 1) ${ }^{39}$

Rajakaruna's anxiety about women who stained themselves with lustful touches was a new concern for the Sinhala poet in the early twentieth century. It was a concern, along with temperance, spiritual purification, linguistic conservatism, and chastity, that marked the poetic moment of departure of Ananda Rajakaruna.

\section{A POETIC MOMENT OF MANEUVER}

Perhaps the most famous anticolonial poet in Sri Lanka was the Venerable S. Mahinda of Tibet. Rajakaruna's admirer and close colleague, Mahinda was born around 1901 in what is known today as Sikkim, the small Indian state in the Himalayan Mountains. Mahinda spelled his name in Sinhala as "Tibat Jātika Es Mahinda" to imitate the custom of naming a monk after his village. ${ }^{40}$ It is possible that he identified himself as S. Mahinda of Tibet since he believed that many Sri Lankans knew of Tibet's Buddhist heritage. ${ }^{41}$

Because Mahinda's most famous poems were Buddhist-oriented didactic works that campaigned for independence, Sunil Ariyaratne suggests that Mahinda sought to link the Buddhist revival to the independence movement. ${ }^{42}$ Indeed, Mahinda wrote some of his most famous poems to incite Sinhalese people into anticolonial action. I discuss three such poems in this section. Consider the first two stanzas of Nidahasē Dähäna (The trance of independence; n.d.). He assumed the voice of a military commander and ordered his Sinhalese readers to fight for freedom:

What [horrible] fate [has befallen us]! We are still not awake.

It is no use to jump around and hide in fear.

It matters not whether we win or lose.

If we do not go forward we will never achieve independence.

Wherever you go, use your national voice like lightning

Shed your sweat on the land of Lanka.

Think seriously about independence and do not make jokes.

Why can't you raise the victory flag of our nation? (vv. 1-2) ${ }^{43}$

In a similar poem, Nidahasē Mantraya (The independence mantra; n.d.), Mahinda used imperatives to urge the Sinhalese to struggle against colonialism. 
Look at [the ancient Sinhalese kingdoms] of Pollonnaruwa and Anuradhapura!

Consider the previous independence we enjoyed in those kingdoms.

Raise your strong young voice.

Go forward, stand up, and do not shut your two eyes. (v. 17)

Here, Mahinda put in stark contrast the glory of the Sinhalese Buddhist past with the bleakness of the colonized present. He bestowed on his readers a heroic role that transcended the part they played in everyday life.

One of Mahinda's most popular nationalist poems was Daru Nälavilla Hevat Jàtika Totilla (The national cradle, also known as the children's lullaby; n.d.). The main character in the poem was an unnamed Sinhalese mother, ostensibly Mother Lanka. At the commencement of the poem, Mahinda depicted her lulling her children to sleep with a well-known Sinhala cradlesong. ${ }^{45}$ Because every line hereafter in Daru Nälavilla comprised twelve syllables like the lines of the lullaby, one may infer that Mahinda intended his audience to keep the lullaby in mind while reading the rest of the poem. The remainder primarily focused on episodes from the Mahāvamsa about the glorious Sinhalese past. The poem thus cleverly blended together a Sinhala lullaby with the stories of the Mahâvamsa chronicle.

Why did Mahinda use the heroes of the Mahāvamsa as characters in the text of a lullaby? One reason he mixed together the lullaby and the Mahâvamsa was that he sought to point to the disparity between the present as lived by Sinhalese mothers and children in colonial Sri Lanka and the putatively illustrious past as lived by the heroes of the Mahâvamsa. Pointing to this dissimilarity was one of Mahinda's strategies to incite his readers into anticolonial action. ${ }^{46}$

Thus, in some stanzas Mahinda alluded to the idea that the sleeping son-and, by extension, all sons of Sinhalese mothers-were continuations of the Sinhalese bloodline found in all the heroes of the Mahāvamsa. According to Mahinda, Sinhalese sons living in the colonial era were destined to take control of the island of Sri Lanka like the ancient Sinhalese heroes of the Mahāvamsa. But to do so they would have to battle against the British to gain for the island independence from colonialism. For example, when the mother rocked her son in the cradle she compared him to the first Sinhalese king of Sri Lanka, Vijaya. According to the Mahāvamsa, Vijaya conquered Sri Lanka with the help of his followers and became king. Here is the stanza that the mother sang to her sleeping son about Vijaya:

As I rock my son [in the cradle]

I remember how Vijaya

And his retinue united

[Our island known then as] Tammänna (v. 4) ${ }^{47}$ 
The poem also compared the mother to the ancient Buddhist monk Mahinda, the son of the Mauryan overlord Ashoka. According to the fourteenth chapter of the Mahāvamsa, Mahinda brought the Buddhist faith to Sri Lanka. Like Mahinda taught the Sinhalese the Buddhist doctrine, all Sinhalese mothers, Mahinda suggested, should introduce to their sons the teachings of Buddhism:

When the Arahat Mahindu arrived

The citizens of Lanka bent their heads.

As he poured the highest teachings of Buddhism

I will pour these teaching into you, my son (v. 11) ${ }^{48}$

Given the back-and-forth between anticolonial nationalism and Buddhist nationalism, one can understand why Sunil Ariyaratne would suggest that Mahinda's primary objective was to link the Buddhist revival to the independence movement.

\section{A MUSICAL MOMENT OF COMMODIFICATION}

I have thus far argued that Chatterjee's theory of the moments of departure and maneuver has clear correlates in the song and poetry of colonial Sri Lanka. In the concluding section of this chapter, I hope to reveal that one weakness of Chatterjee's theory of nationalist thought is that it does not account for the relationship between cultural nationalism and cultural commodities. The following section explores one instance of this relationship in the manner in which Buddhist revivalism made its way into the creation of Sinhala gramophone songs.

A few years after John De Silva's "Dannō Budungē" premiered in Sri Lankan theaters, talent scouts from gramophone record labels such as His Master's Voice (HMV), Odeon, and Parlophone came knocking at De Silva's door. ${ }^{49}$ Record labels felt that nurthi songs like De Silva's "Dannō Budunge"” were the most marketable for the local population. Nearly every song that labels in Sri Lanka released between 1906 and 1930 were songs from the nurthi theater. During this period gramophone players became status symbols of affluent homes in urban areas in Sri Lanka. ${ }^{50}$

When nurthi's popularity started to fade in Sri Lanka, however, so did gramophone records of theater song. Labels began to experiment in the 1930s with a genre they called alut sindu (new music). In 1930 the record label Parlophone released six double-sided alut sindu records. ${ }^{51}$ Throughout the fourth decade powerful labels such as Parlophone, Broadcast, Odeon, HMV, and Columbia released a steady stream of this new genre. Many of these songs, like nurthi songs, revolved around issues related to Buddhism and edification. If nurthi songwriters like De Silva utilized song to strengthen the Buddhist revival, alut sindu songwriters drew on the sentiments of the revival to sell records.

Although the themes of these songs were predominantly culled from the revival, the melodies were taken from Indian film songs. Such "tune-borrowing" is known as parody in Western musicological discourse..$^{2}$ The moment Hindi- or Tamil-lan- 
guage films premiered in Sri Lankan theaters, producers at HMV or Columbia took note of the trendy film songs. Both labels immediately introduced into the Sri Lankan market new Sinhala-language songs, albeit with the very melodies from these Hindi- or Tamil-language film songs. The majority of the new gramophone songs were thus musical imitations. Since imitation was the musical source for new music, the Sinhala-language word for tune was anunäda, which means "echo." 53

Columbia and HMV would pay Sinhalese lyricists five to ten rupees to fashion new lyrics according to the tunes of popular Hindi- or Tamil-language film songs. The labels did not print the names of lyricists on their gramophone records; thus the names of many gramophone-era song lyricists are mostly unknown. ${ }^{54}$ Lyricists would compose words loosely based on the film song's melody and its lyric's patterns of short and long syllables. ${ }^{55}$

Let us consider one concrete example. In 1940 the Hindi-language film titled Bandhan became the second highest grossing Hindi film that year. A very popular song in this movie was the patriotic "Chal Chal Re Naujawan" (Walk, walk, along, young one). After Bandhan premiered in Sri Lanka, the Columbia record label hired a composer to create a musical arrangement to the melody of "Chal Chal Re Naujawan." Columbia also hired a lyricist to compose new words to this melody, words that would be suitable for the Sinhalese Buddhist consumer. The final product was "Dul Sal Vanē Lakal" (The shining and beautiful sal tree in the forest). It was a song about the tree under which Queen Maya gave birth to the Buddha. The lyricist of "Dul Sal Vanē Lakal" not only transformed the patriotic Hindi composition into a Buddhist song but also adroitly imitated the short and long syllabic instants in the Hindi song text (ex. 1)..$^{6}$

EXAMPLE 1. Similar melody and short and long syllabic instants in the Hindi-language "Chal Chal Re Naujawan" and Sinhala-language "Dul Sal Vanē Lakal."

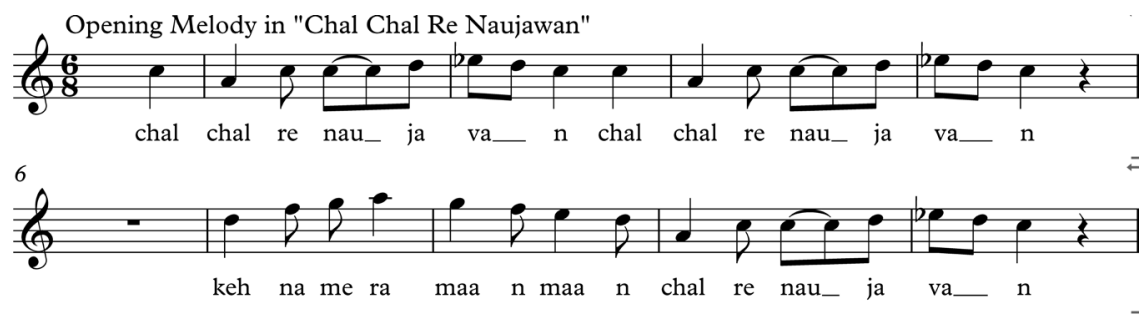

11 Opening Melody in "Dul Sal Vanē Lakal"

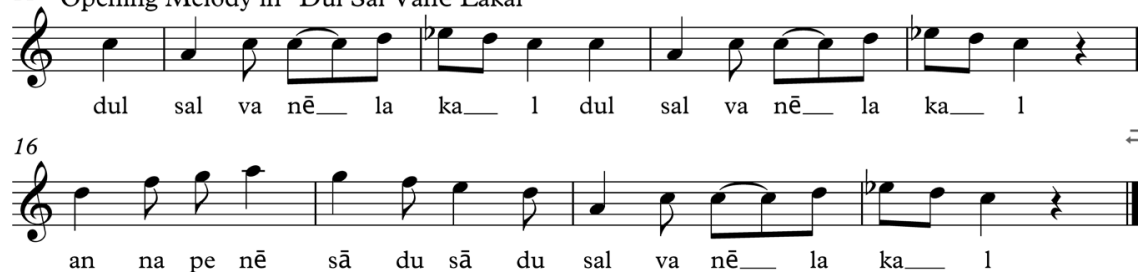


Columbia must have been happy with the sales of "Dul Sal Vanē Lakal," because they released another, "Dul Mallikā Kusum" (The shining jasmine flowers), set to the same film song melody. HMV also released their imitation of this Hindi song, titled “Tel Mal Pudā Vandim” (We'll worship, offering flowers and oil).57

In the heat of competition, Columbia and HMV imitated each other's successful Buddhist songs. In 1939, for example, Columbia released "Muni Nandana Sri Pāda Vandim” (We worship Muni Nandana’s Sri Pāda). It was about a group climbing Sri Pāda, a popular pilgrimage site, where many Sinhalese Buddhists believe Lord Buddha visited:

We worship Muni Nandana’s [Lord Buddha's] Sri Pāda.

We please our hearts and obtain peace, compassion, and joy

While the sweet smell of liberation wafts around this Butterfly

Mountain. ${ }^{58}$

HMV subsequently put out a song with a similar title, "Sri Gautama Sri Pāda Vandim” (We worship Sri Gautama’s Sri Pāda).

We will worship Gautama [Lord Buddha] at Sri Pāda

Wishing for the delightful comfort of the beautiful nirvana ${ }^{59}$

Labels in Sri Lanka did not try to hide the fact that they were producing imitations of Hindi or Tamil film tunes. On the contrary, record labels could sell more records if they notified in advertisements the specific film song from which the new Sinhala song had been built. In 1939 HMV put out a Sinhala song titled "Pita Dīpa Dēśa Jaya Gattā Ādi Sinhalun” (Our Sinhalese ancestors used to be victorious over other countries). The melody imitated the tune of a Tamil film song titled "Divya Darisanam."

"Divya Darisanam" had appeared in the then longest running Tamil-language film, Cintāmani (1937). To market their product, HMV unabashedly advertised the Sinhala song as a "Rāga from Cintammaṇi." The new song was among a batch of edificatory gramophone-era Sinhala songs. It ridiculed the "kalu-suddā" (lit. blackwhite), a pejorative for Sinhalese people who had embraced Western ways of living.

Our Sinhalese ancestors used to be victorious over other countries

But today our kalu suddā roll their tongues out toward Western ways of life.

They foolishly grin and wait at the ocean until food and dress arrive from abroad.

Our Sinhalese ancestors used to be victorious over other countries Now mothers eat imported rice from abroad.

They are no longer accustomed to herali batala (jackfruit and sweet potatoes). Because we have no milk in this country we import milk power and give it to our children, who will perish ${ }^{60}$ 
The song advised Sinhalese people to return to Arya-Sinhala Buddhist customs and advocated strengthening the local economy. Such a song illustrated a form of local commercialism in which a sentiment of the Sinhalese Buddhist revival was itself revived as a song theme set to a catchy melody of a popular Indian film song. If John De Silva, Ananda Rajakaruna, and Tibet S. Mahinda composed song and poetry to cure various colonial-era illnesses that they believed afflicted their downtrodden people, gramophone songwriters sought to capitalize on the momentum of their projects.

In this chapter I have endeavored to disclose several fundamental features of Sinhala song and poetry created during the colonial period of the early twentieth century. Its mode of existence was local, yet its conditions of possibility were cosmopolitan in regard to the spread of Parsi theater, the force of anticolonial nationalism, and the growth of the Indian film industry. In the following chapter, I return to the work of Partha Chatterjee to reflect on the strengths and weaknesses of his widely accepted notion of the inner domain. 